This Journal is available in Telkom University online Journals

Jurnal Manajemen Indonesia

\title{
Consumer Preference Influence Towards Revenue Optimization for Local Brand Accessories in Bandung
}

\author{
Raden Aswin Rahadi ${ }^{1}$ and Shanaya Ratu Shafira ${ }^{2}$ \\ 1,2 School of Business and Management, Institut Teknologi Bandung (SBM-ITB), Bandung, Indonesia
}

\begin{abstract}
Planning a careful market and good product strategy in launching new products is very important to help new company succeed in the market with knowing the consumer preference and cashflow projection. This research raises the issue of the importance of consumer preference to get optimal revenue on launching new product. This research was conducted at Soigne, a local brand accessory in Bandung. The purpose of this study is to determine how the company conducts feasibility study through consumer preferences for knowing the suitable price and products to launch in 2019. This study also analyses the sensitivity analysis to delimit the changes of financial conditions. According to the result of the research, there are recommendations that can be applied in Soigne to launch a suitable product to gain optimal revenue based on consumer preference. The best combination product to launch in Soigne is accessories product between earrings, bracelet, and necklace with neutral color, simple design, and price range between IDR 100,000.00 to IDR 250,000.00. Customer service, packaging design, materials and durability is other factor that important to provide by the company. For the optimal revenue, Soigne recommended to launch earrings with price IDR 149,000.00, bracelet with price IDR 169,000.00, and necklace with price IDR 189,000.00 in the next one year and increase 10\% for the price in the next two and three years which are the best financial scenario of researcher projection.
\end{abstract}

Keywords-Cashflow Projection, Consumer Preference, Feasibility Study, Launching New Product, Sensitivity Analysis

\begin{abstract}
Abstrak
Merencanakan pasar yang cermat dan strategi produk yang baik dalam meluncurkan produk baru sangat penting untuk membantu perusahaan baru berhasil di pasar dengan mengetahui preferensi konsumen dan proyeksi arus kas. Penelitian ini mengangkat masalah pentingnya preferensi konsumen untuk mendapatkan pendapatan yang optimal dalam meluncurkan produk baru. Penelitian ini dilakukan di Soigne, aksesori merek lokal di Bandung. Tujuan dari penelitian ini adalah untuk menentukan bagaimana perusahaan melakukan studi kelayakan melalui preferensi konsumen untuk mengetahui harga dan produk yang cocok untuk diluncurkan pada tahun 2019. Studi ini juga menganalisis analisis sensitivitas untuk membatasi perubahan kondisi keuangan. Menurut hasil penelitian, ada rekomendasi yang dapat diterapkan di Soigne untuk meluncurkan produk yang sesuai untuk mendapatkan pendapatan yang optimal berdasarkan preferensi konsumen. Produk kombinasi terbaik untuk diluncurkan di Soigne adalah produk aksesoris antara anting, gelang, dan kalung dengan warna netral, desain sederhana, dan kisaran harga antara Rp 100.000,00 hingga Rp 250.000,00. Layanan pelanggan, desain kemasan, bahan dan daya tahan adalah faktor lain yang penting untuk disediakan oleh perusahaan. Untuk pendapatan yang optimal, Soigne merekomendasikan untuk meluncurkan anting-anting dengan harga Rp 149.000,00, gelang dengan harga Rp 169.000,00, dan kalung dengan harga Rp 189.000,00 dalam satu tahun ke depan dan meningkat $10 \%$ untuk harga dalam dua dan tiga tahun ke depan yang merupakan yang terbaik skenario keuangan proyeksi peneliti.
\end{abstract}

Kata kunci- Proyeksi Arus Kas, Preferensi Konsumen; Studi kelayakan, Meluncurkan Produk Baru, Analisis Sensitivitas 


\section{INTRODUCTION}

The creative economy is contributed significantly to national economic growth. In 2015, this sector contributed 852 trillion rupiah to national GDP (7.38\%), absorbed 15.9 million workers (13.90\%), and export value of US \$ 19.4 billion (12.88\%). In creative economy, fashion is the second largest contributor to gross domestic product (GDP) after culinary (Munaf, 2018). In 2015, regarding the classification of products purchased online in 2015, the fashion and accessories sector had the highest percentage of 37.6\% (Indonesia Ministry of Communication and Information). Bandung is one of 99 districts / cities in Indonesia that became top three in the largest number of economic businesses with a single business network in creative industry with total amount 5.68\% (Badan Ekonomi Kreatif \& Badan Pusat Statistik , 2017). Planning a careful market and good product strategy is very important to help new company succeed in the market. Companies compete more than ever to develop new and unique products or services and get a higher position in the market. The company develops a large number of new products every year. (Philip, 2009) suggests that there is a new product development process, which includes: making ideas, filtering ideas, developing and testing concepts, developing marketing strategies (marketing strategies) development, business analysis, product development, market testing, and commercialization. In each process, management will decide and to continue or stop the process of developing new products. However, one of the riskiest processes is the development of new products because it's requires high focus and investment (Cooper, 2001).

The threat of new entrants brings new capacity and a desire to gain market share. This puts pressure on prices, costs, and the rate of investment necessary to compete in the industry. When the threat of new entrants is high, existing companies must hold down their prices or boost investment to deter new entrants (Porter, 1979). (Suad \& Muhammad Suwarsono, 2000) stated that the purpose of the feasibility study was to avoid too much investment in non-profitable activities. According to (Kasmir \& Jakfar, 2007) a business feasibility study has the objective conducting a project or business, which is avoid the risk of losses, facilitate planning, facilitating job implementation, facilitating supervision, makes company control easier. Moreover, a company needs consumer to buy our product based on their preferences (Atkinson, 2014). According to (Kotler, 2000, p. 154) consumer preference shows their preferences from various choices of existing service products. If the company follows the customer preference, the company can develop products or services that are suitable for the market. In markets, services or products that are close to customer preference tends to be chosen (Pisharodi, 1994). After all, to get the optimal benefit, prepare the financial scenario using sensitivity analysis, which is a technique to indicates how far the response of net present value changing in to a given change in a variables (Brigham \& Houston, 2001, p. 552).

Soigne, as a two years existing company in fashion accessories industry based in Bandung needs to compete with the preceding company and also the new entrants to keep the business sustain. In 2019, Soigne will launch a new product to optimize their revenue that suitable with their market segment which is women who live in Bandung and Jakarta in age range of 18-24 years old with income more than Rp 1,500,000 and having fashionable lifestyle, and having high to medium usage rate of using social media and high to medium frequency of purchasing accessories in a year. One of to do so is considerate the feasibility study of the company through customer perception to get the optimal benefit.

\section{RESEARCH METHODOLOGY}

Research design is a structured framework for generating data to answer research questions. This study measures the consumer preferences of local brand accessories in Bandung that require large numbers of samples, so it is preferred to use a quantitative approach (Bryan and Bell, 2015). From the calculation, minimum number of samples for this research is 100 people. The respondent will be the same with our segment, Female who use makeup between 15-35 Years Old. Who lives in Bandung and Jakarta and uses social media Instagram daily.

The researcher collect data from primary and secondary data. Questionnaire will be used in order to gather the primary data about suitable price and ideal product for local brand accessories in Bandung. Researcher also use financial data of Soigne for the primary data. The questionnaire designed using Likert scale with 1 to 6 range of scale. Number 1 will represents strongly disagree and up until number 6 will represents strongly agree. The secondary data collected from textbook, journal, and research publication which focusing in feasibility studies and customer preferences as supporting foundation of this research. 
The sample population for this research are focusing on female in Bandung with age range between 18-24. Based on (Badan Pusat Statistik Kota Bandung, 2018) the target respondent amount is around 238,209 people. The sample size of population above 100,000 is 100 people with assumption that the level of precision is $\pm 10 \%$, level of confidence is $90 \%$, and $\mathrm{P}=.1$ (Israel, 1992). This research is use non-probability random sampling for the sampling technique. Non-probability random sampling is chosen because it is impossible to mention all the population for this research.

When the questionnaire is fully covered, the data will be analysed by using SPSS which is the tools for analyse the data. Validity and Reliability also Conjoint Analysis will be used to analyse the data. The result of SPSS will be validity, reliability, correlation, and respondent preference of willingness of purchase that could figure out the suitable price and ideal product for local brand accessories in Bandung.

\section{RESULT AND DISCUSSION}

\section{A. Validity and Reliability}

The first property is validity, which is whether an instrument really measures what you want to measure. The second is reliability, which is whether an instrument can be interpreted consistently in different situations (Field, 2009).

Table 1. Validity

\begin{tabular}{|l|l|l|}
\hline Items & Pearson Correlation & Sig. (2-tailed) \\
\hline Unique Design & 0.350 & 0.000 \\
\hline Color & 0.575 & 0.000 \\
\hline Trend & 0.534 & 0.000 \\
\hline Price & 0.522 & 0.000 \\
\hline Materials & 0.548 & 0.000 \\
\hline Packaging Design & 0.702 & 0.000 \\
\hline Customer Service & 0.637 & 0.000 \\
\hline Offline Store Location & 0.577 & 0.000 \\
\hline Durability & 0.639 & 0.000 \\
\hline
\end{tabular}

Based on table 1 above, the result of Pearson correlation for each variable with significant level at 0.000 , That validity test is using Pearson correlation shows all of the items are valid with significant at $\mathrm{p}<0.01$ with score greater than 0.254 based on R table Pearson, all the of the item is valid (Field, 2009).

Table 2. Reliability Test

\begin{tabular}{|c|c|}
\hline $\begin{array}{c}\text { Cronbach's } \\
\text { Alpha }\end{array}$ & N of items \\
\hline 0.710 & 9 \\
\hline
\end{tabular}

According to table 2 above, the result have Cronbach's alpha 0.710 which is reliable because (Sugiyono, 2012) said the value of a good reliability coefficient is having a Cronbach's alpha above 0.7 . 
Table 3.. Pearson Correlation

\begin{tabular}{|c|c|c|c|c|c|c|c|c|c|}
\hline $\begin{array}{c}\text { Pearson } \\
\text { Correlation }\end{array}$ & $\begin{array}{c}\text { U- } \\
\text { nique } \\
\text { De- } \\
\text { sign }\end{array}$ & Color & Trend & Price & $\begin{array}{c}\text { Materi- } \\
\text { als }\end{array}$ & $\begin{array}{c}\text { Packa- } \\
\text { ging } \\
\text { Design }\end{array}$ & $\begin{array}{c}\text { Custo- } \\
\text { mer } \\
\text { Service }\end{array}$ & $\begin{array}{c}\text { Offline } \\
\text { Store } \\
\text { Loca- } \\
\text { tion }\end{array}$ & $\begin{array}{c}\text { Dura- } \\
\text { bility }\end{array}$ \\
\hline $\begin{array}{c}\text { Unique } \\
\text { Design }\end{array}$ & 1 & $.214^{*}$ & .011 & $.192^{*}$ & .062 & $.215^{*}$ & .072 & .042 & .137 \\
\hline Color & $.214^{*}$ & 1 & $.256^{* *}$ & $.330^{* *}$ & .166 & $.293^{* *}$ & $.294^{* *}$ & $.239^{* *}$ & $.348^{* *}$ \\
\hline Trend & .011 & $.256^{* *}$ & 1 & $.205^{*}$ & .167 & $.314^{* *}$ & $.263^{* *}$ & .084 & .175 \\
\hline Price & $.192^{*}$ & $.330^{* *}$ & $.205^{*}$ & 1 & $.271^{* *}$ & .164 & .090 & $.306^{* *}$ & $.256^{* *}$ \\
\hline Materials & .062 & .166 & .167 & $.271^{* *}$ & 1 & $.246^{* *}$ & $.264^{* *}$ & .161 & $.500^{* *}$ \\
\hline $\begin{array}{c}\text { Packaging } \\
\text { Design }\end{array}$ & $.215^{*}$ & $.293^{* *}$ & $.314^{* *}$ & .164 & $.246^{* *}$ & 1 & $.472^{* *}$ & $.335^{* *}$ & $.352^{* *}$ \\
\hline $\begin{array}{c}\text { Customer } \\
\text { Service }\end{array}$ & .072 & $.294^{* *}$ & $.263^{* *}$ & .090 & $.264^{* *}$ & $.472^{* *}$ & 1 & $.383^{* *}$ & $.373^{* *}$ \\
\hline $\begin{array}{c}\text { Offline } \\
\text { Store } \\
\text { Location }\end{array}$ & .042 & $.239^{* *}$ & .084 & $.306^{* *}$ & .161 & $.335^{* *}$ & $.383^{* *}$ & 1 & $.307^{* *}$ \\
\hline Durability & .137 & $.348^{* *}$ & .175 & $.256^{* *}$ & $.500^{* *}$ & $.352^{* *}$ & $.373^{* *}$ & $.307^{* *}$ & 1 \\
\hline
\end{tabular}

Based on table 3 above, there are several variables that valid and high correlation which are color and durability with significant at the level 0.348 , trend and packaging design with significant at the level 0.314 , price and color with significant at the level 0.330 , packaging design and durability with significant at the level 0.352 , customer service and packaging design with significant at the level 0.472 , offline store location and customer service with significant at the level 0.383 and the highest correlation is between materials and durability with significant at the level 0.500 .

\section{B. Conjoint Analysis}

In the opinion of (Hair, Jr, \& Barie, 2006), conjoined analysis is a multivariate technique used to understand how respondents build preferences for products or services. The analysis can also be used for designing price, predict the level of sales or product use (market share), test new product concepts, segment preference, product combination and designing promotional strategies.

Table 4. Conjoint Test

\begin{tabular}{|c|c|c|}
\hline \multirow{2}{*}{ Utilities } & Value & Std. Error \\
\hline \multicolumn{3}{|c|}{ Color } \\
\hline Neutral & 1.185 & .591 \\
\hline Colorful & -1.185 & .591 \\
\hline \multicolumn{3}{|c|}{ Design } \\
\hline Simple & .118 & .591 \\
\hline Bold & -.118 & .591 \\
\hline \multicolumn{3}{|c|}{ Price } \\
\hline $100,000-250,000$ & .355 & .591 \\
\hline $250,001-500,000$ & -.355 & .591 \\
\hline (Constant) & 4.500 & .591 \\
\hline
\end{tabular}


This conjoint analysis consists of three main utility with two variables for each. First utility is color with options neutral and colorful, the second utility is design with options simple and bold, and the third utility is price with option 100,000-250,000 and 250,001-500,000. Based on table 4 above, the result is neutral color be the most important utility with score 1.185 , then simple design with score 0.118 , and 100,000-250,000 for price with score 0.355 . The constant score based on the table is 4.500 which means it is the base score where can be change by adding the other variables tested. Because all utilities are expressed in shared units, they can be added together to provide highest total utility to get the best combination. So, by combine the value of constant, neutral color, simple design, and price $100,000-250,000$ or $1.185+0.118+0.355+4.500$ it will be 6.158 or the most optimal value that respondent already chooses. In other words, the optimal value result based on consumer preferences is neutral color, simple design, and price range between IDR 100,000.00 - IDR 250,000.00.

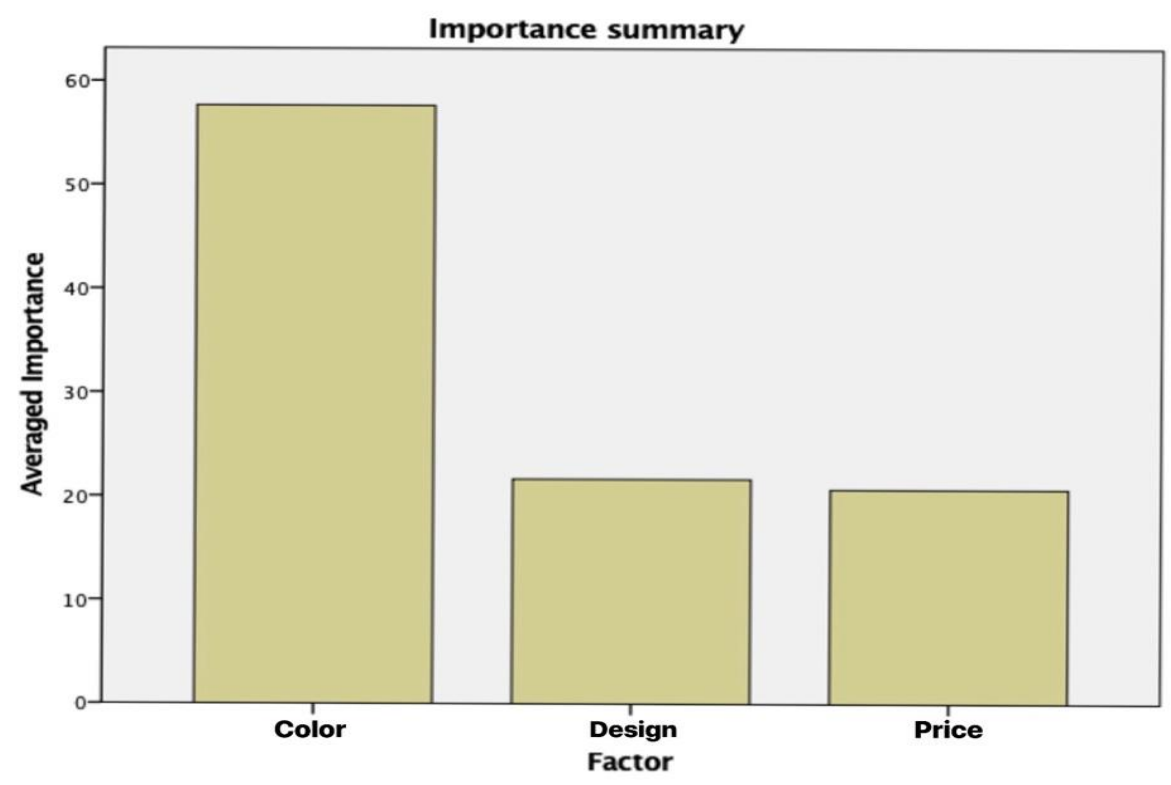

Figure 1. Important Summary

The figure 1 above shows the result of the most importance utility is color, the second is design factor, then the lowest is price.

\section{Consumer Preference}

The result of questionnaire that researcher conducted, accessories that most often purchased is earrings with $38 \%$ response, bracelet with $28 \%$ response and necklace with $15 \%$ response shown on figure 1 below.

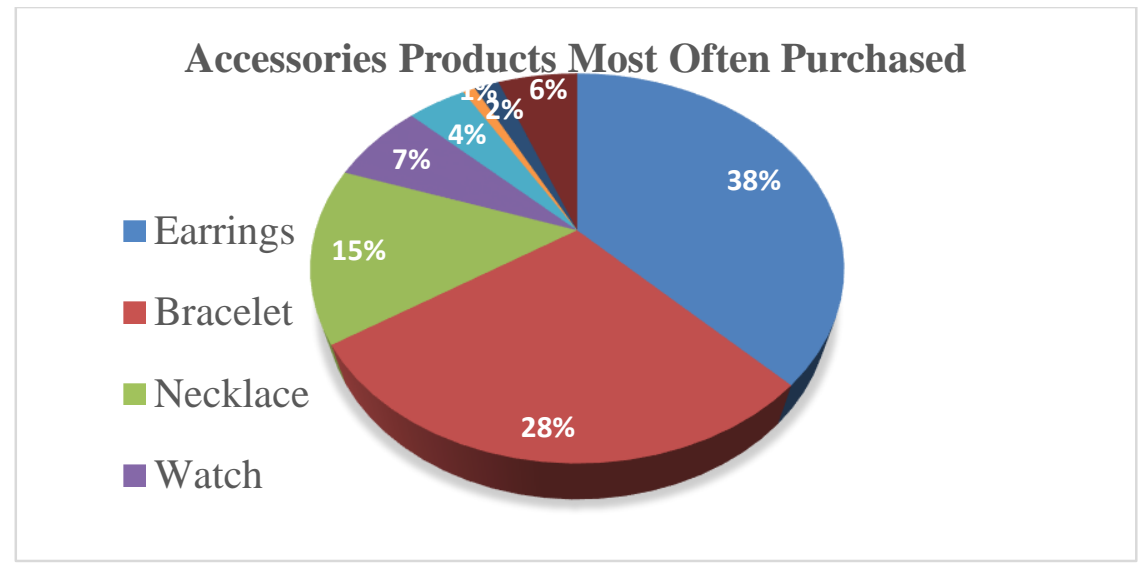

Figure 2. Accessories Product Most Often Purchased (Source: Author's analysis) 


\section{Cashflow Projection}

This research conducts a cash flow projection for the next three years based on previous financial data of Soigne, result of conjoint analysis and consumer preferences for the best combination utility in one product. There are three scenarios of cash flow projection with different kind of condition which are best, normal, and worst. The best condition is having the maximum selling price, the worst condition is having the minimum price, then the normal one is the average price between best and worst with the price increase $10 \%$ every year (Deloitte, 2018).

Table 5. Price Scenario

\begin{tabular}{|l|l|r|r|r|}
\hline \multirow{4}{*}{ Accessories } & Scenario & Price on 2019 (IDR) & Price on 2020 (IDR) & Price on 2021 (IDR) \\
\hline \multirow{4}{*}{ Earrings } & Best & 149,000 & 163,900 & 180,290 \\
\cline { 2 - 5 } & Normal & 139,000 & 152,900 & 168,190 \\
\cline { 2 - 5 } & Worst & 109,000 & 119,900 & 131,890 \\
\hline \multirow{3}{*}{ Bracelet } & Best & 169,000 & 185,900 & 204,490 \\
\cline { 2 - 5 } & Normal & 149,000 & 163,900 & 180,290 \\
\cline { 2 - 5 } & Best & 129,000 & 141,900 & 156,090 \\
\hline \multirow{3}{*}{ Necklace } & Best & 189,000 & 207,900 & 228,690 \\
\cline { 2 - 5 } & Normal & 169,000 & 185,900 & 204,490 \\
\cline { 2 - 5 } & Best & 144,000 & 158,400 & 174,240 \\
\hline
\end{tabular}

(Source: Author's analysis)

With price scenarios, the result for cashflow projection is shown below. In table 6 the projection for cash in that consist of beginning cash and revenue for each scenario with the highest amount in best scenario which is IDR 93,560,500.00 and the lowest amount in worst scenario which is IDR 79,630,340.00.

Table 6. Cash in Projection

\begin{tabular}{|c|r|r|r|}
\hline \multicolumn{4}{|c|}{ Total Cash in Projection (IDR) } \\
\hline Year/Scenario & Best Scenario & Normal Scenario & Worst Scenario \\
\hline $2017-2018$ & $3,429,000$ & $3,429,000$ & $33,429,000$ \\
\hline $2018-2019$ & $24,222,000$ & $23,067,000$ & $21,807,000$ \\
\hline $2019-2020$ & $80,182,540$ & $74,455,110$ & $68,222,850$ \\
\hline $2020-2121$ & $93,560,500$ & $86,510,040$ & $79,630,340$ \\
\hline
\end{tabular}

In table 7, cash out projection consist of initial investment on 2017-2018 and all expenses, the best scenario has the highest amount because author add more marketing cost and salaries.

Table 7. Cash Out Projection

\begin{tabular}{|c|c|c|c|}
\hline \multicolumn{4}{|c|}{ Cash Out Projection (IDR) } \\
\hline Year/Scenario & Best Scenario & Normal Scenario & Worst Scenario \\
\hline $2017-2018$ & $45,073,508$ & $45,073,508$ & $45,073,508$ \\
\hline $2018-2019$ & $14,847,485$ & $14,674,235$ & $14,485,235$ \\
\hline $2019-2020$ & $38,190,120$ & $36,781,313$ & $36,392,074$ \\
\hline $2020-2121$ & $41,790,790$ & $40,161,353$ & $39,727,798$ \\
\hline
\end{tabular}

(Source: Author's analysis) 


\section{E. Feasibility Study}

In this part, each scenario be calculated for the net present value (NPV), internal rate of return (IRR), and payback period. If NPV is positive $(>0)$, it will be accepted and reliable to be invested (Kahneman \& Miler, 1986). For IRR, it is rationale when its greater than discounted rate of Weighted Average Cost of Capital or WACC (Belyadi \& Belyadi, 2017). WACC are obtained from calculation of risk-free rate based on Bank Indonesia which is $6 \%$ per year or $0.5 \%$ per month, expected market return, and beta of the industry. Below the formula of Capital Asset Pricing Market (CAPM):

$$
E R i=R f+\beta i(E R m-R f)
$$

Where:

$E R i=$ Expected Return of Investment

$R f=$ Risk Free Rate

$\beta i=$ Beta of Industry

$E R m=$ Expected Return on Market

$$
\begin{gathered}
\text { ERi }=0.5 \%+1.171448(0.853 \%-0.5 \%) \\
\text { ERi per month }=0.914 \% \\
\text { ERi per year }=11 \%
\end{gathered}
$$

Below are the calculation of net present value (NPV), internal rate of return (IRR), and payback period for each scenario in total four years.

Table 8. Value of NPV, IRR, and Payback Period

\begin{tabular}{|c|c|c|c|}
\hline Scenario & NPV (IDR) & IRR & Payback Period \\
\hline Best & $68,736,557$ & $88 \%$ & 25 months 7 days \\
\hline Normal & $60,383,201$ & $76 \%$ & 25 months 8 days \\
\hline Worst & $49,962,643$ & $61 \%$ & 25 months 9 days \\
\hline
\end{tabular}

(Source: Author's analysis)

Based on Table 8 above shows the Net Present Value (NPV) is accepted in three scenarios which are best, normal, and worst scenario with the highest NPV IDR90,355,186. For the result of IRR above are acceptable because it is greater than WACC value which is $11 \%$ and IRR of the industry according to (Deloitte, 2018) which are $21 \%-30 \%$ or $>30 \%$.

\section{F. Sensitivity Analysis}

To get the optimal revenue, the feasibility study result that consist of NPV, IRR, and payback period will be tested with sensitivity analysis by changing the demand and cost. There will be four tests for each scenario, first is demand increased $10 \%$ with cost decreased $10 \%$, the second is demand decreased $10 \%$ with cost increased $10 \%$, then demand increased $20 \%$ with cost decreased $20 \%$, and the last demand decreased $20 \%$ with cost increased $20 \%$. So, it will have twelve result to be compared.

Table 9. First Sensitivity Test (Source: Author's analysis)

\begin{tabular}{|l|c|c|c|}
\hline \multicolumn{4}{|c|}{ Demand $+10 \%$ and Cost $-10 \%$} \\
\hline & Best Scenario & Normal Scenario & Worst Scenario \\
\hline NPV (in idr) & $83,495,960$ & $70,306,660$ & $49,279,488$ \\
\hline IRR & $112 \%$ & $96 \%$ & $67 \%$ \\
\hline
\end{tabular}


Table 10. Second Sensitivity Test (Source: Author's analysis)

\begin{tabular}{|l|c|c|c|}
\hline \multicolumn{4}{|c|}{ Demand $-10 \%$ and Cost $+10 \%$} \\
\hline NPV (IDR) & Best Scenario & Normal Scenario & Worst Scenario \\
\hline IRR & $46,746,142$ & $39,844,701$ & $31,144,064$ \\
\hline Payback in Month & $60 \%$ & $48 \%$ & $31 \%$ \\
\hline
\end{tabular}

Table 11. Third Sensitivity Test (Source: Author's analysis)

\begin{tabular}{|l|c|c|c|}
\hline \multicolumn{4}{|c|}{ Demand $+20 \%$ and Cost $-20 \%$} \\
\hline NPV (IDR) & Best Scenario & Normal Scenario & Worst Scenario \\
\hline IRR & $96,816,361$ & $86,811,054$ & $74,196,729$ \\
\hline Payback in Month & $128 \%$ & $117 \%$ & $101 \%$ \\
\hline
\end{tabular}

Table 12. Fourth Sensitivity Test (Source: Author's analysis)

\begin{tabular}{|l|c|c|c|}
\hline \multicolumn{4}{|c|}{ Demand $-20 \%$ and Cost $+20 \%$} \\
\hline NPV (IDR) & Best Scenario & Normal Scenario & Worst Scenario \\
\hline IRR & $35,469,141$ & $25,902,492$ & $18,222,184$ \\
\hline Payback in Month & $41 \%$ & $19 \%$ & $-1 \%$ \\
\hline
\end{tabular}

From the four table above, the highest NPV with amount IDR 96,816,36.00, IRR with the highest percentage which is $128 \%$ and the fastest payback period with only 25 moths 1 days is when the demand increased $20 \%$ and cost decreased $20 \%$ on best scenario. The rest of test are also acceptable except one test on worst scenario when the demand increased $20 \%$ and cost decreased $20 \%$ because the IRR is $-1 \%$ which is $<0$.

\section{CONCLUSION}

The results presented on this research were based on market research aimed to identify consumer preference influence toward revenue optimisation to launch new product with best combination and analyse the sensitivity through cost and price to determine the effect of changes in production parameters on changes in production system to generate optimal revenue. Based on the research, top three accessories that most often purchased by the respondents are earrings, bracelet, and necklace. There are nine factors that influence respondents to purchase given to the them which are unique design, colour, trend, price, materials, packaging design, customer service, offline store location, and durability. From the analysis, there are three importance factor that considered to purchase which are colour, design, and price. The result shows the best combination product to launch is product with neutral colour, simple design, and price range between IDR 100,000.00 to IDR 250,000.00. The result also shows there are high correlation between materials and durability.

This research provides three kind of cashflow scenario for local brand accessories in Bandung based on consumer preference. The cashflow scenario classified into best, normal, and worst scenario aimed to prepare the future financial situation. Furthermore, the current price of Soigne's product has already fit proven by respondent toward consumer price preference. Based on consumer preference, price is not really matter for them 
in choosing accessories product, however, respondents recommend the price range between IDR 100,000.00 to IDR 250,000.00. For current, expected, and consumer price preference has no significant differences.

\section{REFERENCES}

Atkinson, S. (2014). The Business Book. London: Dorling Kindersley Limited.

Badan Ekonomi Kreatif, \& Badan Pusat Statistik . (2017). Profil Usaha/Perusahaan 16 Subsektor Ekraf Berdasarkan Sensus Ekonomi 2016 (SE2016). Badan Pusat Statistik.

Badan Pusat Statistik Kota Bandung. (2018). Retrieved from https://bandungkota.bps.go.id/statictable/2017/08/29/104/jumlah-penduduk-menurut-kelompok-umurdan-jenis-kelamin-di-kota-bandung-2016-.html

Belyadi, H., \& Belyadi, F. (2017). Economic Valuation. Science Direct, 207-261.

Brigham, F., \& Houston. (2001). Dasar-Dasar Manajemen Keuangan. Jakarta: Salemba Empat.

Cooper, R. G. (2001). Winning at New Product. Massachusetts: Persus Publishing Cambridge.

Deloitte. (2018). Fashion \& Luxury Private Equity and Investors Survey 2018.

Field, A. (2009). Discovering Statistic Using SPSS. London: SAGE Publication.

Green, P. E., \& Rao, V. R. (1971). Conjoint Measurement for Quantifying Judgmental Data. Marketing Research.

Hair, J. F., Jr, W. C., \& B. J. (2006). Multivariate Data Analysis. New Jersey.

Indonesia Ministry of Communication and Information. (n.d.). Retrieved from https://statistik.kominfo.go.id/site/searchKonten?iddoc $=1457$

Israel, G. D. (1992). Determining sample size: University of Florida Cooperative Extension Service. Institute of Food and Agriculture Sciences, EDIS.

Kahneman, D., \& Miler, D. T. (1986). Norm Theory: Comparing Reality to Its Alternatives. Psychological Review , 93 (2), 136-135.

Kasmir, \& Jakfar. (2007). Studi Kelayakan Bisnis. Jakarta: Penerbit Prenada Media Group.

Kotler, P. (2000). Manajemen Pemasaran. Jakarta: Prehalindo.

Munaf, T. (2018, June). Head of the Indonesian Creative Economy Agency.

Philip, K. (2009). Manajemen Pemasaran. Jakarta: Erlangga.

Pisharodi, R. (1994). Preference for Supplier When Supplier and Customer Perception of Customer Service Levels Differ. Logistics and Transportation Review, 30.

Porter, M. E. (1979). How Competitive Forces Shape Strategy.

Suad, H., \& Muhammad Suwarsono. (2000). Studi Kelayakan Proyek (Vol. IV). Yogyakarta: Penerbit UPP AMP YKPN.

Sugiyono. (2012). Metode Penelitian Kuantitatif Kualitatif dan R\&D. Bandung: Alfabeta. 